\title{
Hydrographic properties in the São Sebastião Channel: daily variations observed in March 1980
}

\author{
Belmiro Mendes de Castro \& Luiz Bruner de Miranda \\ Instituto Oceanográfico da Universidade de São Paulo \\ (Caixa Postal 66149, 05315-970 São Paulo, SP, Brasil) \\ e-mail: bmcastro@usp.br
}

\begin{abstract}
A four-day quasi-synoptic survey of hydrographic properties sampled from March 4 to March 7, 1980 was used for a physical description of the daily variations in the thermohaline and mass structures in the São Sebastião Channel. Temperature and salinity were sampled down the water column during events of non-tidal along channel current reversals. The observed temperature decrease and density increase in the southern channel bottom layer were mainly due to cold water transported northward by a subsurface current. The northward bottom current opposed the southward main flow in the upper layer. The low temperature and salinity of the water advected northward by the bottom current indicated influences of the South Atlantic Central Water (SACW), inducing a near bottom thermocline-like structure. By the end of the sampling period, the vertical temperature gradient intensified near the bottom and the salinity distribution reached almost uniform conditions.
\end{abstract}

Resumo: Uma amostragem quase sinótica realizada durante quatro dias, no período de 4 a 7 de março de 1980, foi usada para uma descrição de variações das estruturas termohalina e de massa no Canal de São Sebastião. A temperatura e a salinidade foram amostradas na coluna de água durante a reversão do sentido da componente longitudinal da corrente. $O$ decréscimo da temperatura e o aumento da densidade, na entrada sul do canal, foram ocasionados por adveç̧ão de águas próximas ao fundo, com sentido oposto ao do movimento para o sul na camada de superficie. As águas de baixa temperatura, advectadas para o norte, indicam influências da Água Central do Atlântico Sul (ACAS), gerando um gradiente vertical de temperatura nas proximidades do fundo semelhante a uma termoclina. No fim do período do experimento o gradiente vertical de temperatura foi intensificado nas proximidades do fundo e a estrutura halina atingiu condições com fraca estratificação vertical.

Descriptors: Temperature, Salinity, Density, Spatial and daily variations, São Sebastião Channel, South Atlantic Central Water.

Descritores: Temperatura, Salinidade, Densidade, Variações espacial e diária, Canal de São Sebastião, Água Central do Atlântico Sul. 


\section{Introduction}

The São Sebastião Channel (SSC) is located in the NE coast of São Paulo State, between the coastal plain and the São Sebastião Island (SSI). The channel is almost $22 \mathrm{~km}$ long with a curved configuration oriented from $\mathrm{NE}$, in the southern part, to $\mathrm{N}$ in the north. The channel is wider in both entrances $(7.2 \mathrm{~km}$ and $5.6 \mathrm{~km}$, in the south and north, respectively) and narrow in the middle (1.9 km in the Ponta do Araçá) (Fig. 1). There is a deeper main channel located on the island side, with depths of about $25 \mathrm{~m}$ near Ponta da Sela in the south, reaching a maximum depth of about $45 \mathrm{~m}$ near station 14 (Fig. 1), in the central part of the channel. The $20 \mathrm{~m}$ isobath parallels the main channel, defining a closed line in the northern entrance near Ponta das Canas. The adjacent inner shelf is shallower in the north than in the south. Abrupt bottom slopes at the margins characterize the main channel.

The SSC is a region of complex physical processes, including strong wind-driven currents, mixing of water masses of contrasting origins and a well defined seasonal thermocline accompanied by a two-layer baroclinic structure. There are not many published studies about the SSC Physical Oceanography, and most of them are concerned with the circulation. The latter has no strong correlation with the tides, but is highly influenced by the wind (Emilsson, 1962; Kvinge, 1967; Castro, 1990; Fontes, 1995). Castro (1985) applied a barotropic nested numerical model to study the response of the SE Brazilian Shelf to the wind-stress forcing during winter. The author used a hierarchy of three grids with changing space resolution to resolve the SSC, being able to show that currents in the SSC are not entirely locally forced. Being the forcing mechanism primarily the synoptic wind stress, currents in the SSC are strongly connected to the adjacent shelf circulation. Castro \& Lee (1995) have shown that low frequency sea level oscillations, and consequently currents, can be forced remotely by the wind and reach the SSC region in the form of continental shelf waves.

Drift bottles and seabed drifters have also been used to estimate the residual surface and bottom currents (Furtado, 1978; Furtado et al., 1987; Souza \& Castro, 1996*). Results show residual bottom

(*) Souza, M. C. A. \& Castro, B. M. 1996. Comparação dos métodos lagrangeano e euleriano no estudo das correntes no Canal de São Sebastião. In: SIMPÓSIO DE INICIAÇÃO CIENTÍFICA DA UNIVERSIDADE DE SÃO PAULO, ENGENHARIA E EXATAS, 4. São Paulo, USP. Resumos. São Paulo, Ed. Parma. p. 220. currents flowing predominantly towards north, in qualitative agreement with the mean along-channel current measured during the winter of 1979 (Castro, 1990).

Seasonal variations in the SSC hydrographic properties were studied by Ito \& Weber, 1986*; Silva, 1995; and Coelho, 1997. The authors show a strong seasonal signal in the vertical structure. During winter the waters are almost homogeneous in both temperature and salinity. During summer, on the other hand, there is a strong thermocline between mid-depths and the bottom, resembling the baroclinic first mode. The seasonal hydrographic variability within the SSC follows closely the one observed in the adjacent inner shelf (Castro, 1996).

In this paper we describe daily variations of temperature, salinity and density in the SSC due to surface and bottom water masses intrusions. Data and methods are presented the following section. In the next the daily hydrographic variations and their main driving mechanisms are described. Finally, the discussion and conclusions are presented.

\section{Data and methods}

The hydrographic data were sampled in four consecutive days near the summer end (March 4 to March 7, 1980). In order to take measurements as synoptically as possible the following sampling strategy was devised: one day hydrographic sampling along four transversal sections across the channel ( $A$, B, C and D, Fig. 1), on March 4 and 6; a $12 \mathrm{~h}$ anchored station occupied near station 8 , on March 5 , and a longitudinal section along the main channel, on March 7. Sections C and D covered only the deeper part of the channel cross-section.

Cross-section A had four hydrographic stations (stations 1 to 4 ); cross-sections B, C and D had three stations each, consecutively numbered from 5 to 13 . The along-channel survey consisted of five stations (stations 1, 6, 14, 9 and 12). During the sampling on March 4 and 6 two additional stations were located outside the channel, stations 16 and 17 , respectively, (Fig. 1).

(*) Ito, R. G. \& Weber R. R. 1986. Estrutura termohalina e oxigênio dissolvido no Canal de São Sebastião, São Paulo. In: MINI-SIMPÓSIO DE BIOLOGIA MARINHA, 5. São Sebastião, 1986. Resumos. São Paulo, Cebimar. p. 8. 


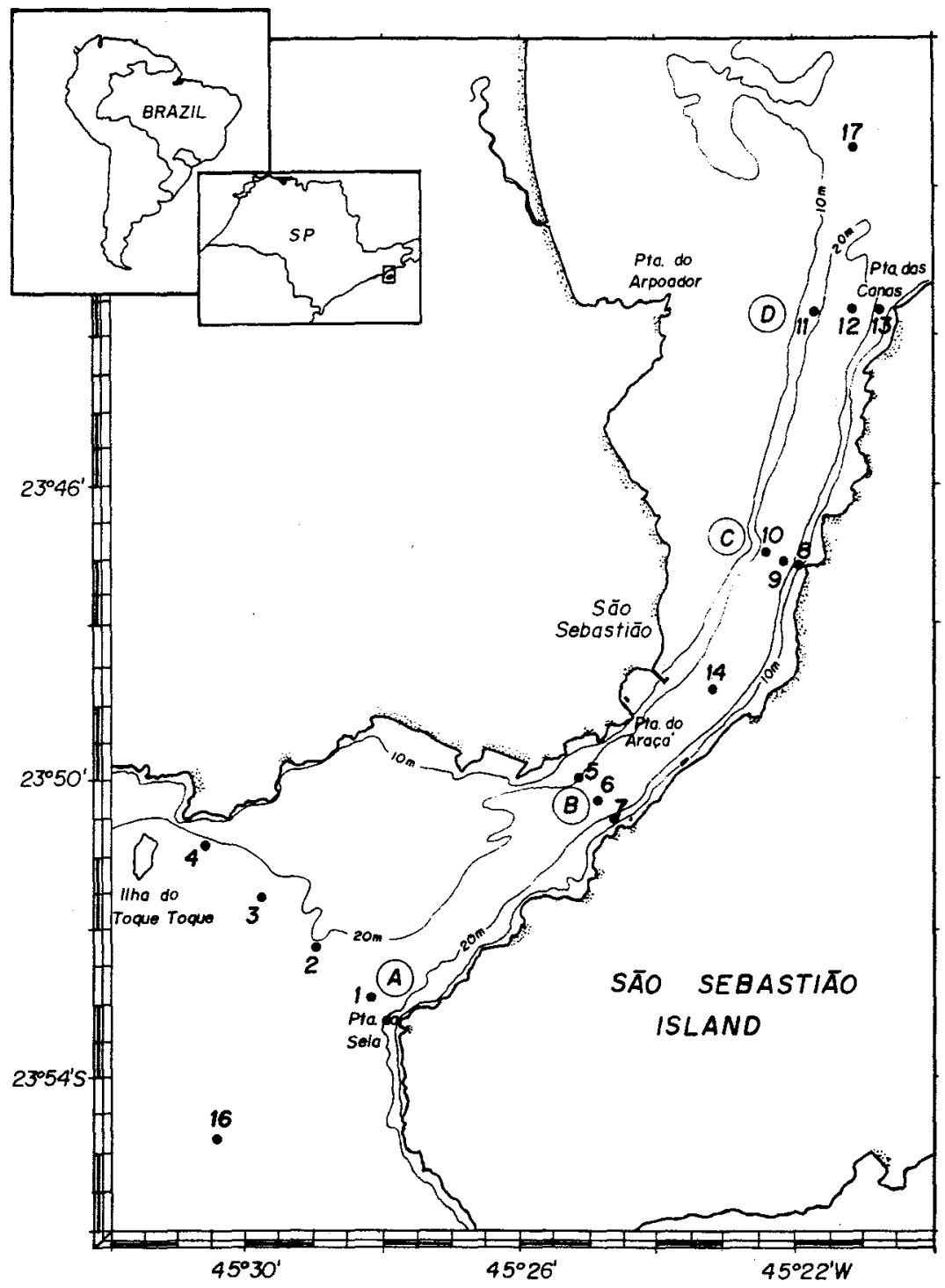

Fig. 1. São Sebastião Channel and position of hydrographic stations (1 to 17).

The fieldwork was conducted aboard the University of São Paulo R/B Emília. Temperature (T) and salinity (S) were observed with a Beckmam Thermosalinograph, model RS-7C, previously calibrated in laboratory and allowing for an accuracy of "in situ" measurements of $\pm 0.2^{\circ} \mathrm{C}$ and $\pm 0.2 \%$, respectively. To prevent influences of the boat structure and water discharge on the instrument cell, the water column was sampled every $5 \mathrm{~m}$ from a depth of about $2 \mathrm{~m}$ down to the bottom. The classical Knudsen Equation of State was used to compute the density anomaly at atmospheric pressure (Sigma-t).
The spatial variations of independent $(\mathrm{S}, \mathrm{T})$ and dependent (Sigma-t) hydrographic properties were analyzed on the basis of vertical structures for cross-channel sections $\mathrm{A}, \mathrm{B}, \mathrm{C}$ and $\mathrm{D}$, and for the along-channel section. For the anchored station, time variability was analyzed with the method of isopleths.

\section{Hydrographic characteristics}

Prior to describing the hydrographic conditions observed in the SSC, it is instructive to 
mention briefly the results obtained by Miranda \& Castro (1995) for the circulation in the same period. Low-pass filtering the sea level oscillation time series, using a 40 -h filter, significantly reduced the variance of the signal (Fig. 2), showing the predominance of the tidal oscillations. The alongchannel current signal, sampled near the Araça Point, on the other hand, had a much weaker variance reduction when low-pass filtered (Fig. 2), showing that the low frequency currents are more energetic than the tidal currents. Once more the observed contrasting behavior between sea level and currents lends support to the idea of quasistationary tidal waves in the SSC (Kvinge, 1967; Fontes, 1995).

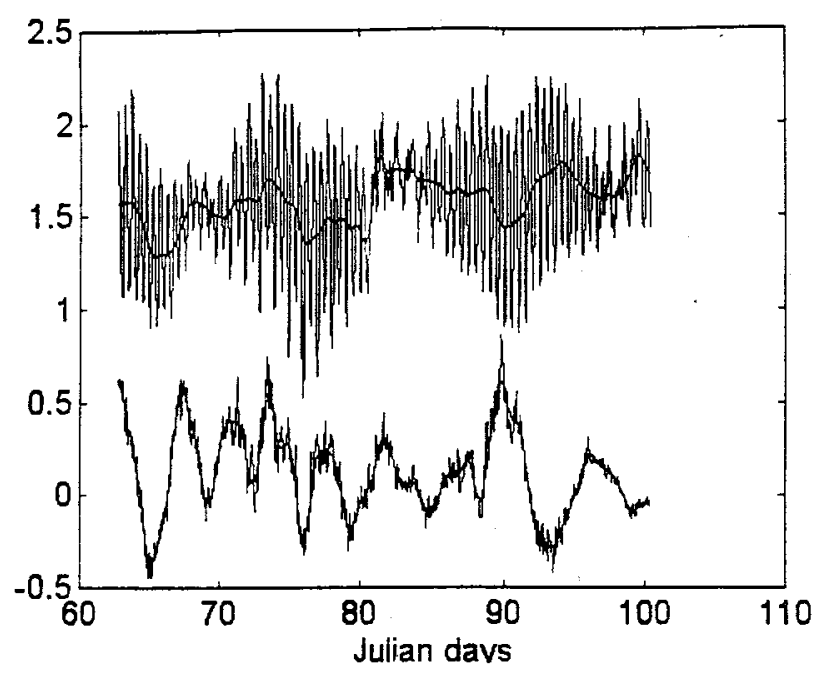

Fig. 2. Original and $40 \mathrm{~h}$ low-passed time series of sea level oscillations (upper figure, in $\mathrm{m}$ ) and alongchannel current component (lower figure, in $\mathrm{m} \mathrm{s}^{-1}$ ) in the São Sebastião Channel, from March 3 (Julian Day 62) to April 10 (Julian Day 101), 1980.

In the beginning of the experiment (March 4; Julian Day 63) the water in the surface layer was flowing northward, with speeds reaching $0.65 \mathrm{~m} \mathrm{~s}^{-1}$ (Fig. 2). The current field sampled along cross section B on March 4, indicated a northward current core of maximum intensity $\left(0.30 \mathrm{~m} \mathrm{~s}^{-1}\right)$, from the surface to the $25 \mathrm{~m}$ level (Fig. 3). Below this core, the current shear intensified and a near bottom southward counter current $\left(-0.10 \mathrm{~m} \mathrm{~s}^{-1}\right)$ was observed. During the first hours of March 5 (Julian Day 64) the velocity direction was variable and its low intensity was an indicator of current reversal. Around noon, the main flow turned southward and reached speeds of $-0.55 \mathrm{~m} \mathrm{~s}^{-1}$. In the next day (March
6; Julian Day 65), a two layer motion across section $B$ was observed, with the upper layer flowing southward having maximum speeds of about 0.20 $\mathrm{m} \mathrm{s}^{-1}$ and the lower layer flowing northward with speeds of $-0.60 \mathrm{~m} \mathrm{~s}^{-1}$ (Fig. 3). The depth of no motion was located at about $15 \mathrm{~m}$ depth. Finally, on March 7 (Julian Day 66), another current reversal was observed, and the hydrographic experiment was conducted under conditions of surface to bottom northward currents with speeds between 0.25 and $0.35 \mathrm{~m} \mathrm{~s}^{-1}$ (Fig. 2).

\section{First observation period}

Hydrographic conditions in section A on March 4 indicated relatively weak and vertical stratification of the thermohaline properties. The downward temperature decrease from 29 to $24^{\circ} \mathrm{C}$ was associated with a salinity increase from 32 to $34 \%$. There was a lens of nearly homogeneous water at mid-depths (Figs $4 \mathrm{~A}$ and $5 \mathrm{~A}$ ). Temperature and salinity fields showed very weak lateral gradients along the section.

Temperature across the narrowest part of the channel (section B) was also and weakly vertically stratified, with values ranging from 29 to $26^{\circ} \mathrm{C}$ (Fig. 4B). The salinity exhibited in the upper layer a downward increase from 32.0 to $33.5 \%$ (Fig. 5B). Beneath this layer the hydrographic conditions were almost homogeneous and the near bottom temperature of $26^{\circ} \mathrm{C}$ was associated with salinities of $34 \%$.

Thermohaline conditions in sections $\mathrm{C}$ and D (Figs 4C,D and 5C,D) were quite similar to the ones observed in section B. There is a small temperature decrease in the bottom layers of section $\mathrm{C}$, with a minimum close to $24.0^{\circ} \mathrm{C}$.

\section{Second observation period}

Isopleths showing the local variability of temperature and salinity during a 12 hours period (from 07:00 to 19:00, local time) are presented in Fig. 6. At the beginning of the sampling period there was a weak and shallow thermocline centered at $7 \mathrm{~m}$ depth, across which the temperature decreased almost $1.5^{\circ} \mathrm{C}$ (from 28.5 to $27.0^{\circ} \mathrm{C}$ ). This thermocline was associated with an increase in the salinity, with values ranging from 32.4 to $33.4 \%$. At $16: 00$ this characteristic of the thermohaline structure had deepened to 12 meters, probably as a result of advection by the southward current. 
ALONG-CHANNEL COMPONENT (m s-1)
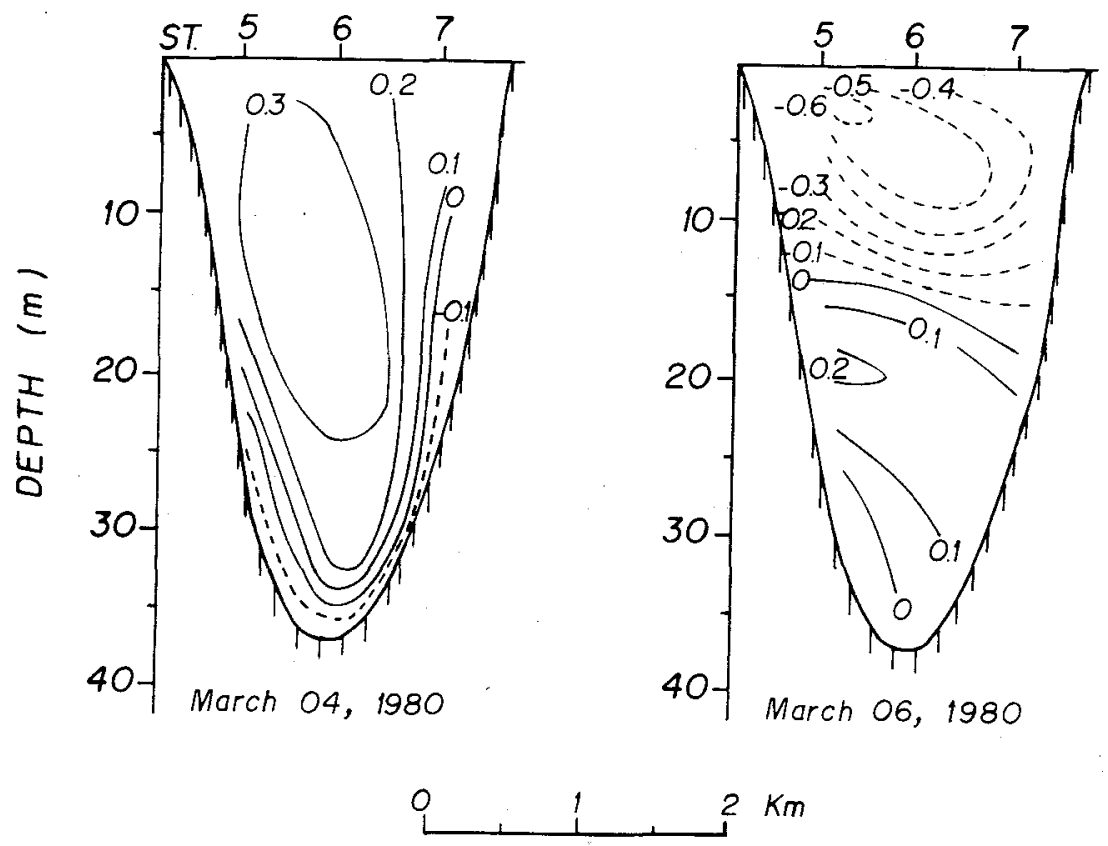

Fig. 3. Vertical structure of the along-channel current component across section B (according to Miranda \& Castro, 1995).

TEMPERATURE $\left({ }^{\circ} \mathrm{C}\right)$
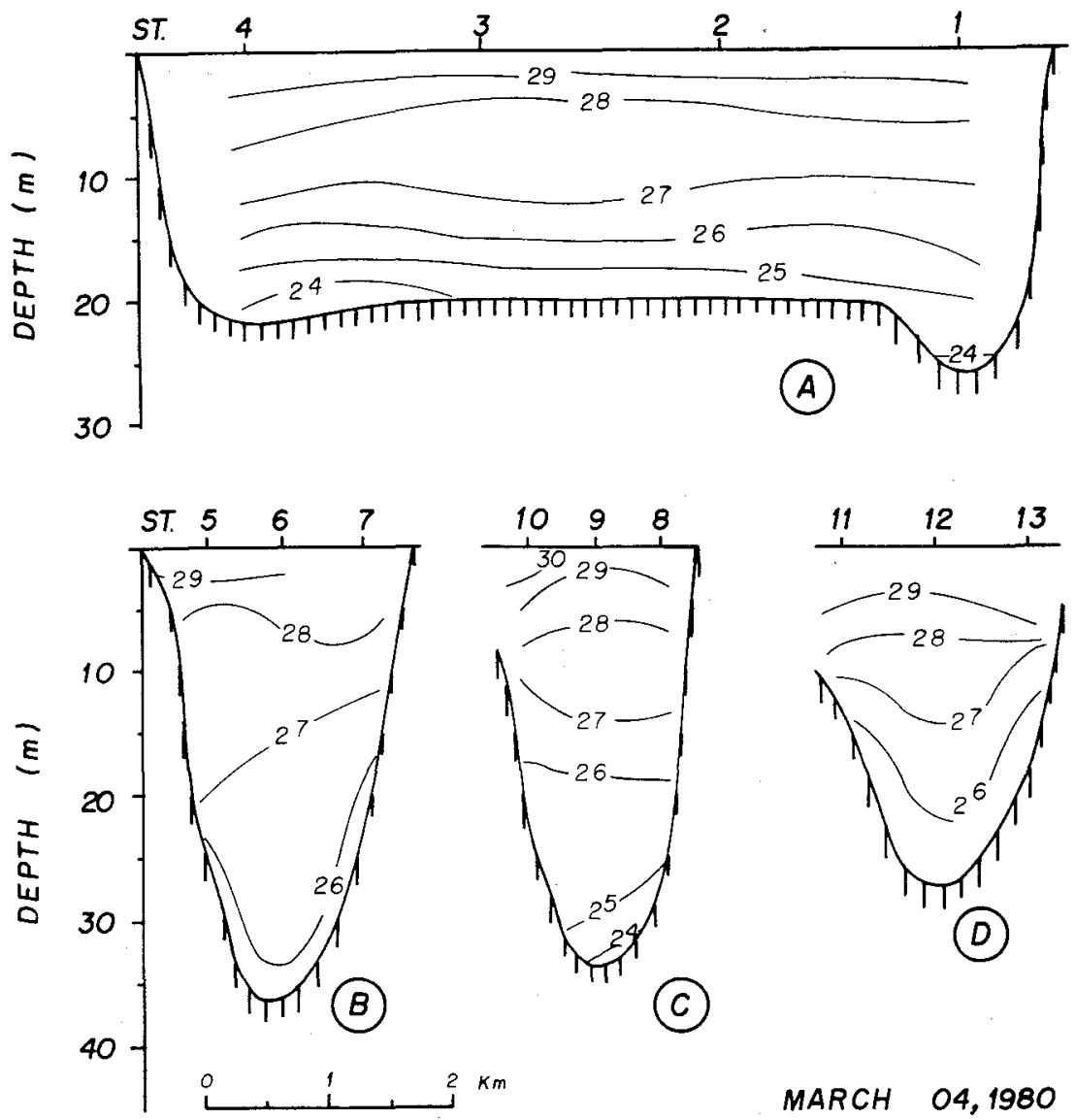

(c)

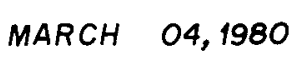

Fig. 4 - Vertical temperature distribution in cross sections A, B, C and D, on March 4, 1980. 
SALINITY $(\% \circ)$
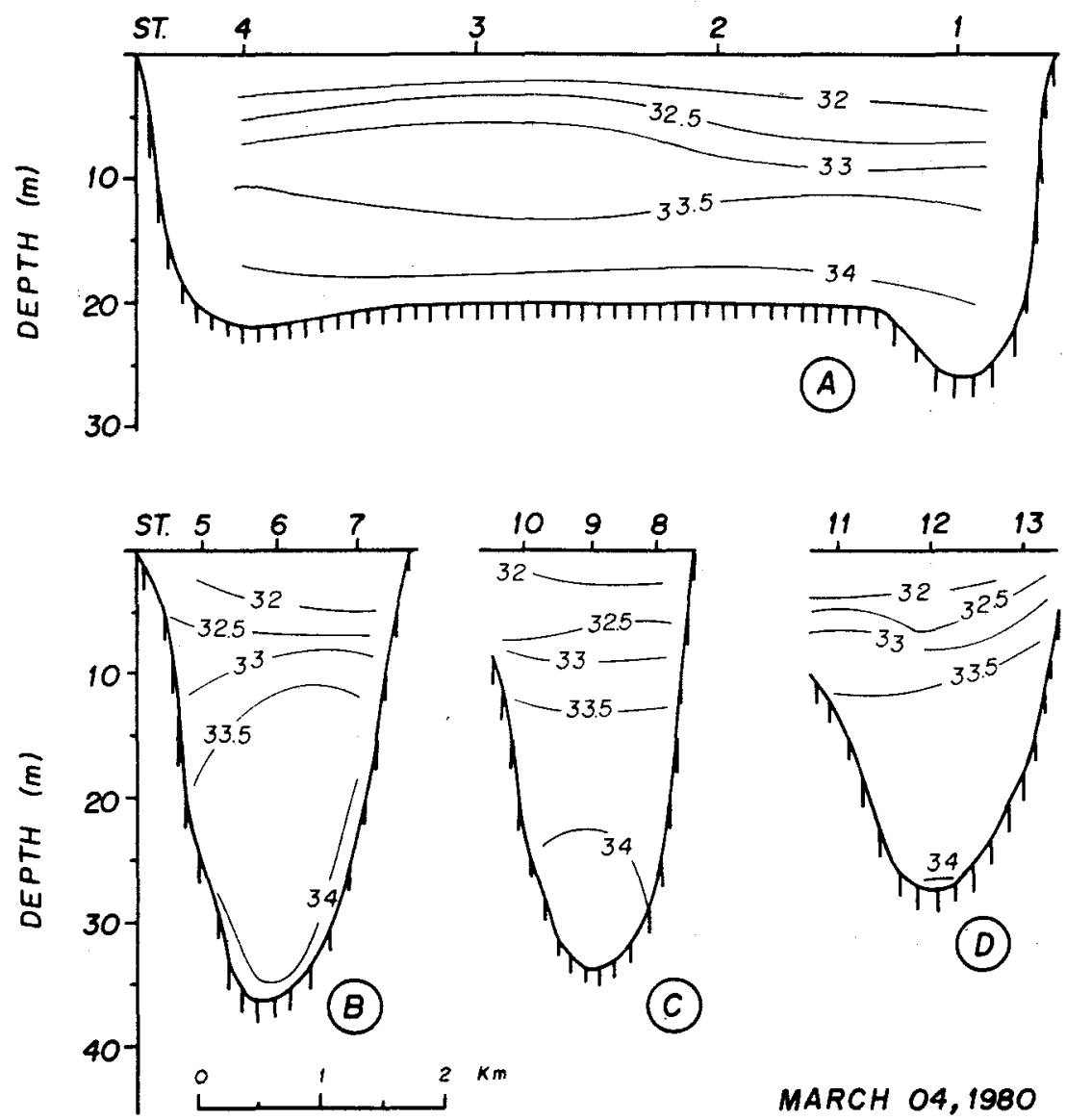

(D)

(c)

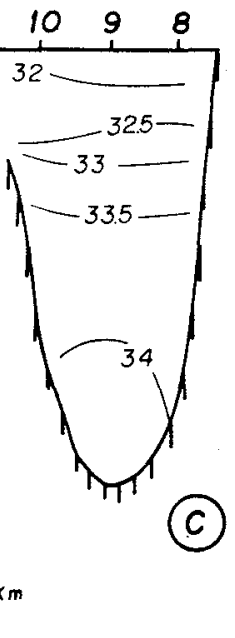

MARCH 04, 1980

Fig. 5 - Vertical salinity distribution in cross sections A, B, C, and D, on March 4, 1980.
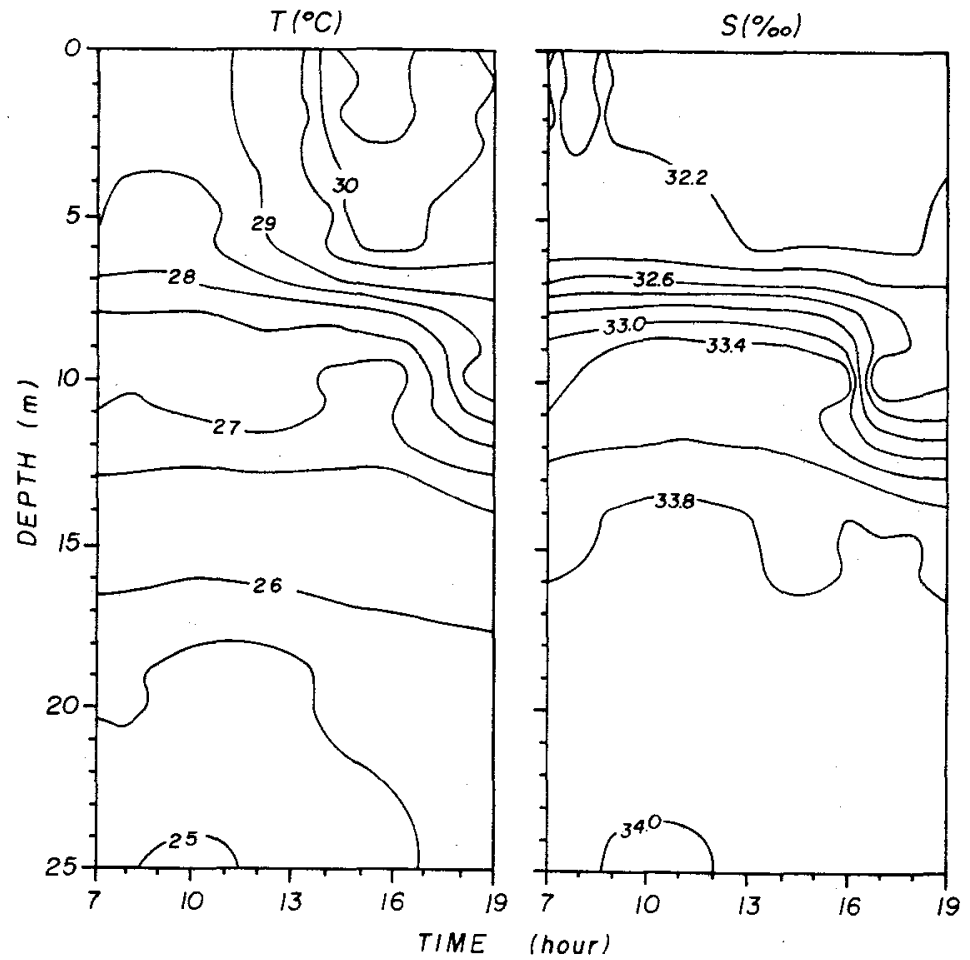

Fig. 6 - Isopleths of thermal and haline structures, on March 5, 1980, from 7:00 $\mathrm{h}$ to 19:00 $\mathrm{h}$ (local time). 


\section{Third observation period}

Comparing the thermal and haline structures (Figs 7 and 8) to the ones observed in March 4 (Figs 4 and 5), it is possible to notice a pronounced change in the near bottom temperature structure in the main channel southern entrance (section A - Figs. 7A and 4A). There was an impressive temperature decrease of about $7.0{ }^{\circ} \mathrm{C}$ (from 24 to $17^{\circ} \mathrm{C}$ ) in about $48 \mathrm{~h}$. Consequently, the southerly intrusion of colder and denser water into the SSC was due to the near bottom northward flow observed on the island side of the channel. The intrusion was responsible for the formation of a near bottom thermocline, not observed on March 4 (Fig. $4 \mathrm{~A})$.

Previous studies (Miranda, 1982; Castro et al. 1987; Miranda \& Katsuragawa, 1991; Castro,
1996) show that during the summer and spring the subsurface layers on the continental shelf offshore of the SSI have relatively low temperatures and high salinities $\left(\mathrm{T}<20.0{ }^{\circ} \mathrm{C} ; \mathrm{S}<36.4 \%\right.$ ). Those values are typical of the South Atlantic Central Water (SACW). The observed near bottom temperature and salinity of about $17^{\circ} \mathrm{C}$ and $34.5^{\circ} \%$ (Figs. $7 \mathrm{~A}$ and $8 \mathrm{~A}$ ) indicate the influence of the SACW.

Thermohaline structures in sections $\mathrm{B}, \mathrm{C}$ and $\mathrm{D}$ showed temperatures decreasing from 29 to $24^{\circ} \mathrm{C}$ and salinities increasing from 32.5 to $34.0 \%$ (Figs. 7B, C, D and 8B, C, D). The relatively high temperatures indicate that the waters influenced by the SACW were confined to southern part of the channel. However, according to Miranda \& Castro (1995), the near bottom motion across section B was also northward. Hence, the SACW intrusion was at an early stage.
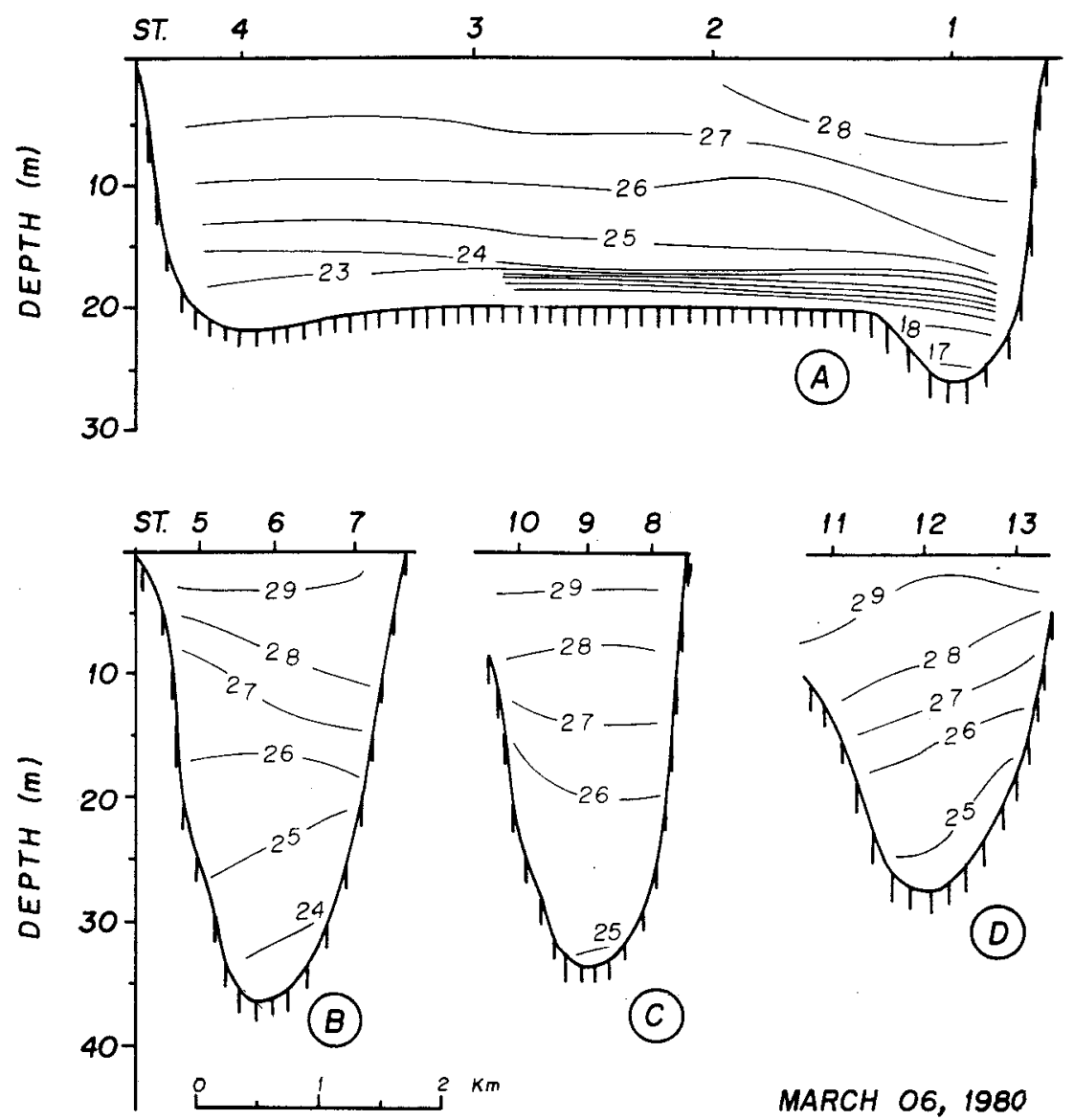

Fig. 7. Vertical temperature distribution in sections A, B, C and D, March 6, 1980. 
SALINITY (\%o)
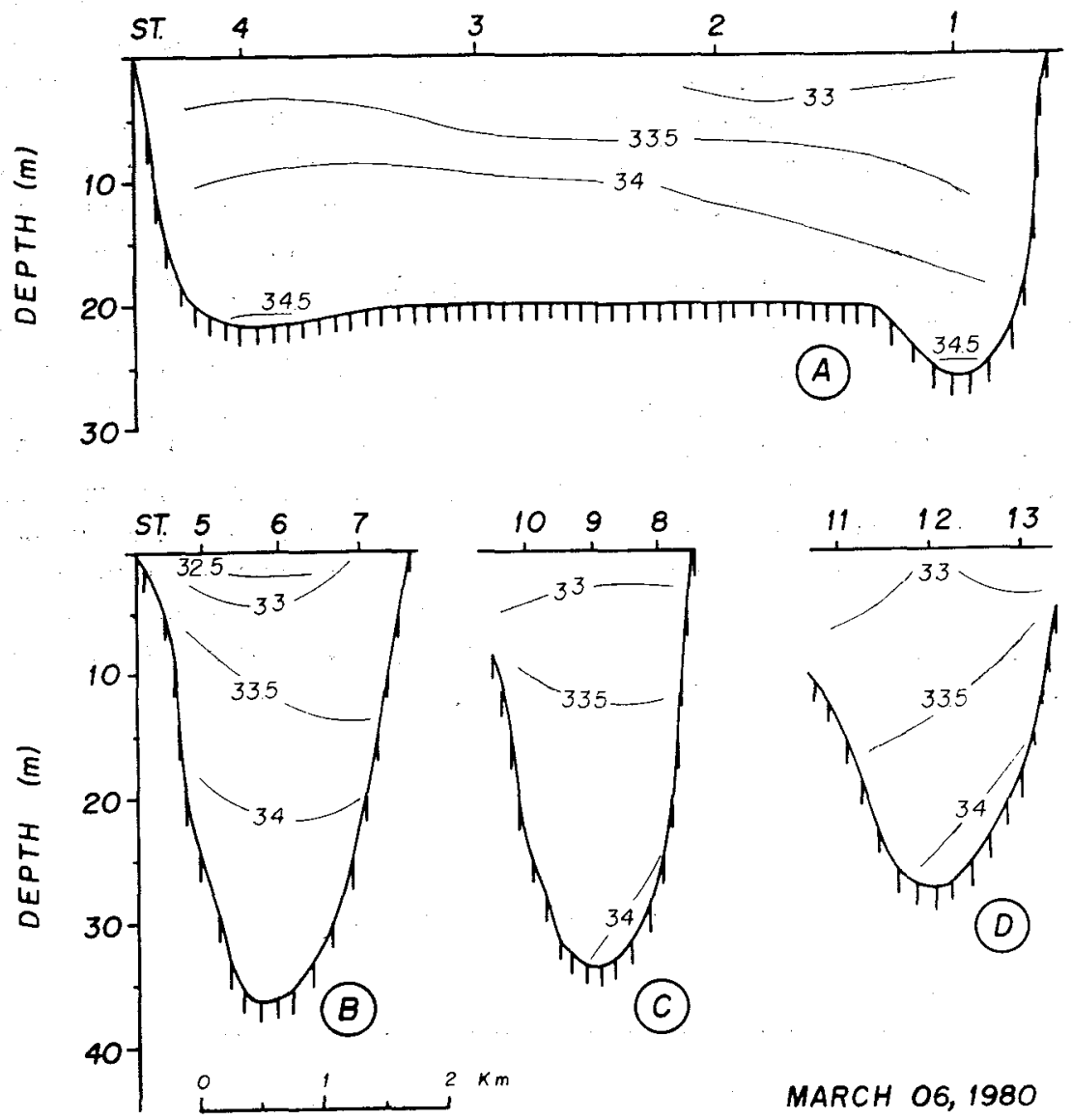

Fig. 8. Vertical salinity distribution in sections A, B, C and D, on March 6, 1980.

The mass structure (Fig. 9) parallels the isotherm configuration. A bottom pycnocline on island side of section A (Fig. 9A) was mainly induced by the thermal changes described above. It is interesting to note the changes in the isopycnals (isotherms) slope downstream, between sections D and B (Figs. 9B, 9D). When the southward coastal current enters the channel the isopycnals slope upward towards the island side, leaving the more dense water to the left of the current. Since the current speed decreases with depth (Fig. 2), this fact disagrees with the classical mass field-current geostrophic adjustment in the southern hemisphere, showing that the currents in the SSC are not geostrophically driven by baroclinicities. In section B the isopycnals slopes were not as pronounced as in the northern section.

\section{Fourth observation period}

On March 7 the hydrographic section was along the main channel. For better visualization of the hydrographic supra-inertial variability, results are presented sequentially in Figs. 10 and 11.
During the period from March 4 to March 7 there were only small changes in the upper layer thermal structure, with a decrease from 29 to $26^{\circ} \mathrm{C}$ in the upper $20 \mathrm{~m}$. However, the bottom thermocline intensified progressively along the channel due to the northward advection of cold water. The near bottom temperature decreased from almost 24 to $17^{\circ} \mathrm{C}$ in the southern entrance, and from 23 to $19^{\circ} \mathrm{C}$ in the middle of the channel (Fig. 10). Consequently, on March 7 the influence of the SACW had already reached section $B$.

In contrast to the thermal structure, salinity variations were observed in the upper layer during the period from March 4 to March 6 . The surface salinity minimum in the southern entrance of the channel $(31.5 \%)$ on March 4 was replaced values near $33.0 \%$ (Fig. 11). Since there was a current reversal, the salinity increase in the upper layer seems to be mainly due to the southward salt transport. The subsurface layer experienced small salinity changes, reaching almost isohaline conditions $(34.0 \%$ ) on March 7. 

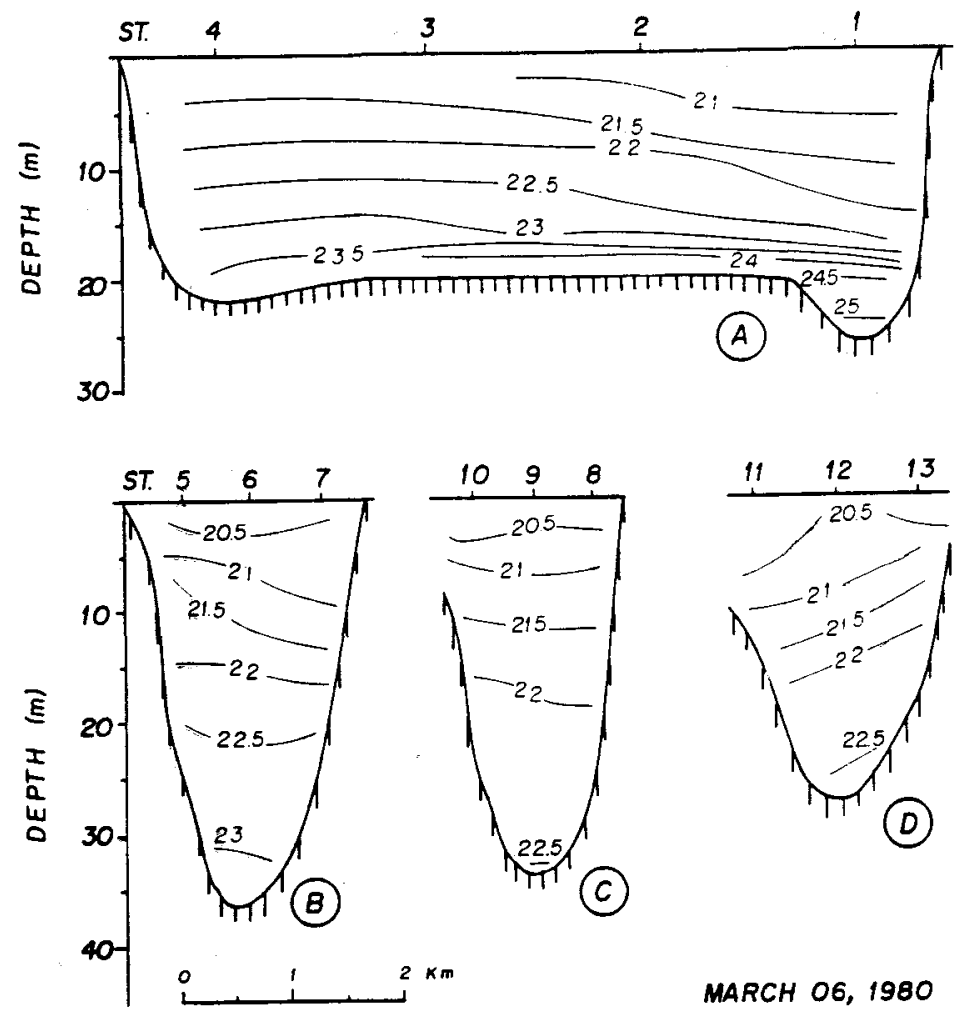

Fig. 9. Vertical density distributions (Sigma-t) in sections A, B, C and D, on March 6, 1980.

\section{Discussion}

During the observation period (March 4 to 7), the $17^{\circ} \mathrm{C}$ water, associated with salinities near $34.5 \%$, was confined to the southern part of the SSC. A comparison between the thermohaline longitudinal structure (Figs 10 and 11) and those observed on February, 1986 (Ito \& Weber, 1986), suggests the possibility of occurrence of the $17^{\circ} \mathrm{C}$ water along the full extension of the channel, associated with salinities as high as $35.0 \%$. It is well known that in the bottom layer on the continental shelf off São Sebastião Island the $17.0^{\circ} \mathrm{C}$, typical of the SACW, is associated with salinities around $35.8 \%$ (Miranda, 1982). During summer, when the influence of the SACW on the adjacent shelf is at a maximum (Castro et al., 1987; Silva, 1995; Castro, 1996), about $50 \%$ of the bottom water has a strong signal of the $\mathrm{SACW}$. It is possible to conclude that during this experiment the SACW, with lower salinities due to dilution by waters of continental origin, was being advected northward through the southern entrance of the SSC as a bottom trapped flow.

As a consequence of the variability in the thermohaline conditions changes in the mass distribution also occurred within subsurface layers of the SSC. There was an increase in density (with a maximum value of about 2 in Sigma-t units, not shown) mainly due to temperature decrease in the subsurface layers. The latter induced an increase in the potential energy of the water column and in the along-channel baroclinic pressure gradient force. The role of this force in the development of a two-layer flow, and advection of the SACW northward along the bottom layer of the SSC, cannot be fully investigated within the context of this data set. There are strong evidences for it being responsible for the against wind flow in the bottom layer (Castro, 1996).

To further describe the hydrographic properties and to synthesize the variability of the temperature, salinity and Sigma-t, the classical T-S diagram was plotted with all the collected (S,T) pairs (Fig. 12). The points on the T-S plane have a small scattering and the curves for each period are well behaved, having similar configurations, what lends support to the possibility of using nearly synoptic hydrographic observations to study mixing processes and water mass formation in the SSC. From this diagram it is also possible to indicate the following intervals for temperature, salinity and Sigma-t, for the period of the experiment: 17 to $30^{\circ} \mathrm{C}, 31.0$ to $34.5 \%$ and 19 to $25 \mathrm{~kg} \mathrm{~m}^{-3}$, respectively. Except for the very low salinities, these values agree with the ones observed by Castro (1996) in the inner and midshelf adjacent to the SSC region. 

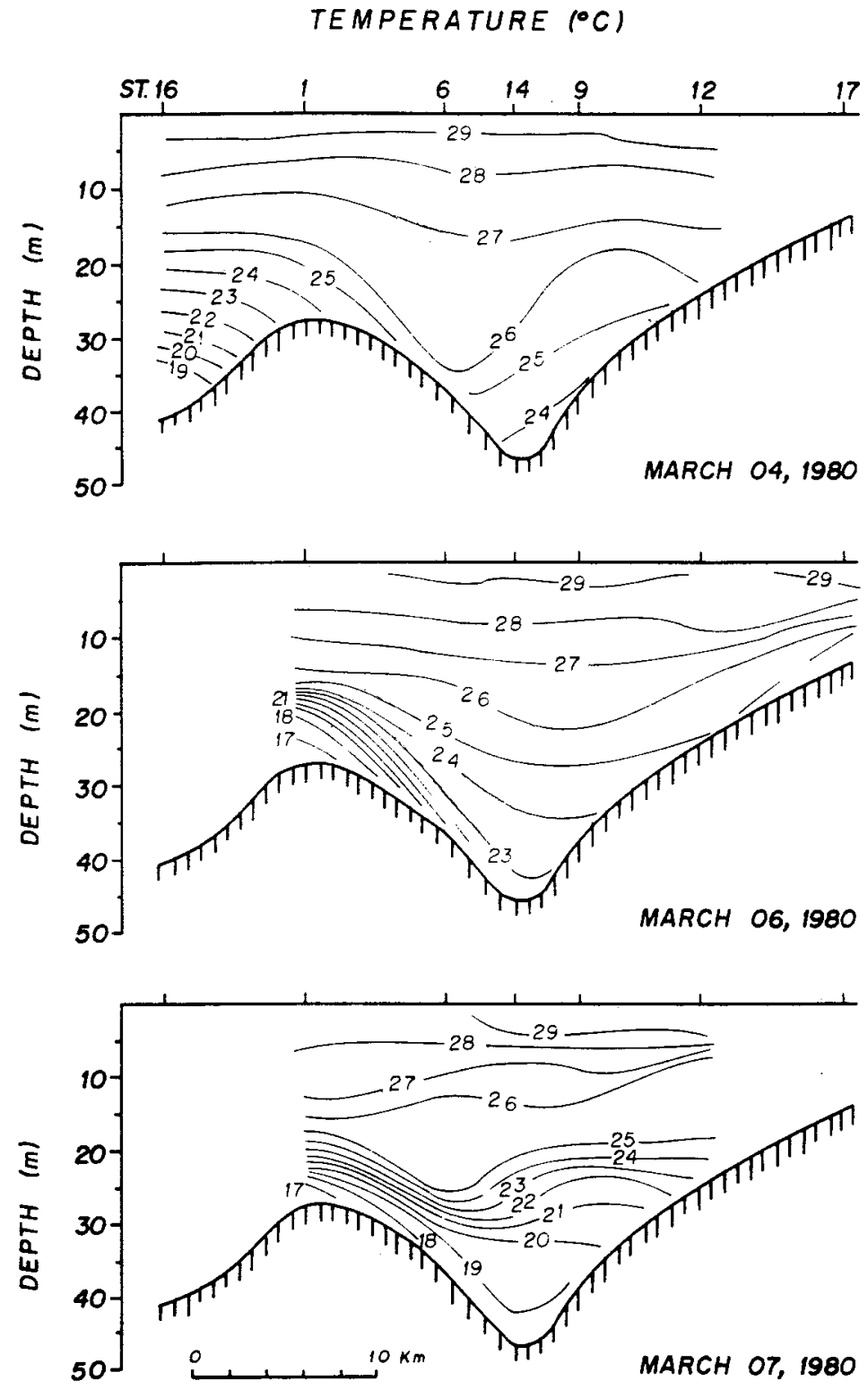

Fig. 10. Daily variations of thermal structure along the main channel, from March 4 to March 7, 1980.

The inner shelf is located between the coast and the Bottom Thermal Front (BTF) which separates the warmer Coastal Water (CW) from the colder SACW (Castro, 1996). During summer, the BTF is located 10 to $30 \mathrm{~km}$ offshore, at depths between $20 \mathrm{~m}$ and $40 \mathrm{~m}$. The main characteristic of the inner shelf is to show, most of the time, strong tendency for vertical homogeneity. The mid-shelf, located offshore from the bottom thermal front shows, on the other hand, a two layer stratification, with the colder and more saline SACW occupying the bottom layer.

Comparing the results of this work with those from Castro (op. cit.) for the adjacent shelf during summer, it is possible to conclude that the observed presence of the SACW in the bottom layer of the SSC is a manifestation of the Bottom Thermal Front intrusion into the channel. Usually, these intrusions occur across the channel southern entrance.

The predominant path for SACW intrusion into the SSC is due mainly to the channel topography. The southern entrance is, in general, deeper than the northern entrance (see the $20 \mathrm{~m}$ isobath in Fig. 1). There is also a relatively deeper channel, which crosses the continental shelf offshore from the SSI connected to the SSC southern entrance. The SACW, being the densest of the continental shelf water masses, fills the deep channels. When winds blow from NE the volume transport induced by the wind drift current is offshore and the subsurface SACW is advected closer to the coast (Castro, 1996), being naturally available for the intrusions through the southern channel entrance. 


\section{SALINITY (\%o)}
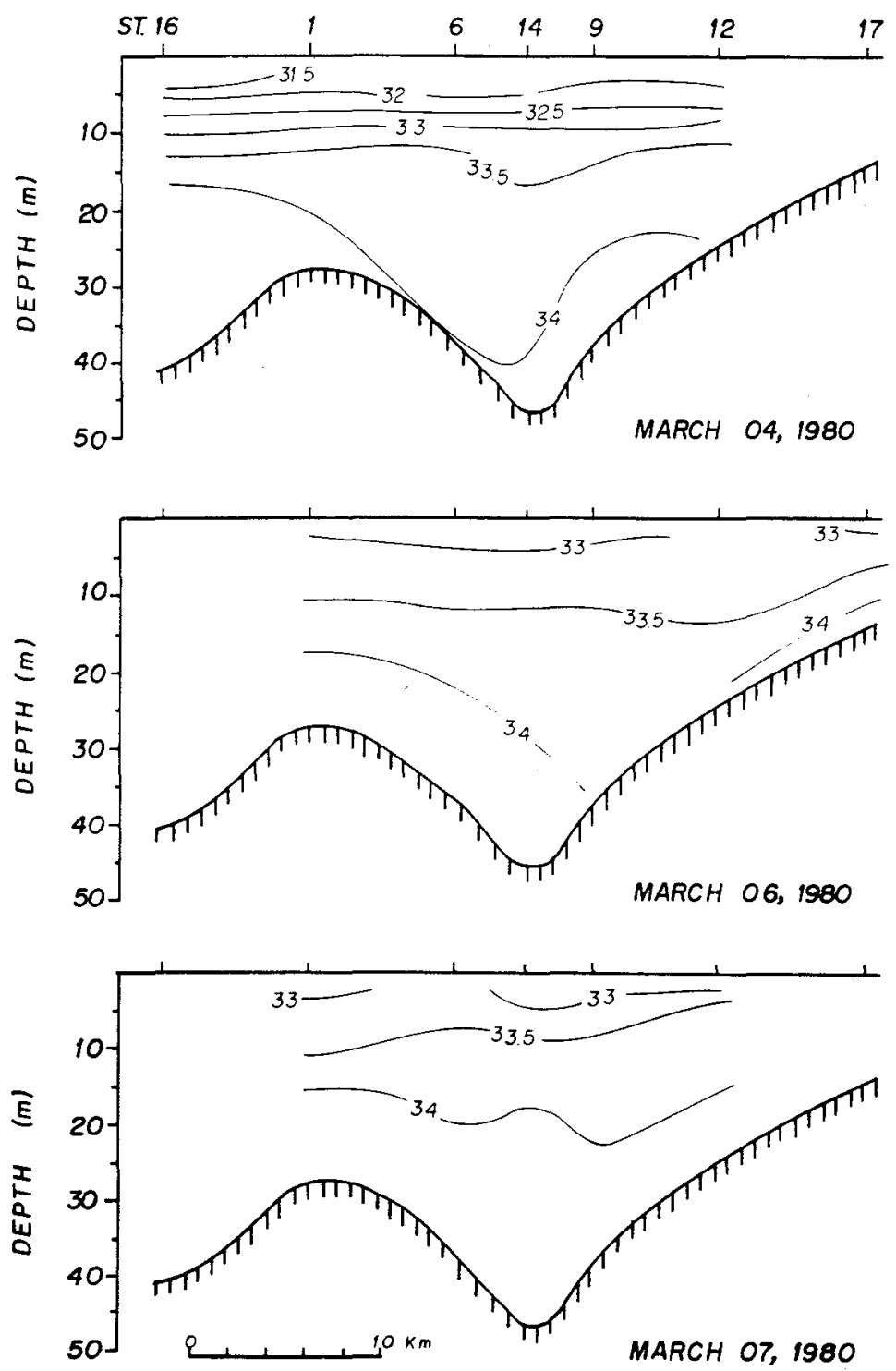

Fig. 11. Daily variations of haline structure along the main channel, from March 4 to March 7,1980 .

\section{Conclusions}

Daily variability of hydrographic properties observed along the São Sebastião Channel were associated with advection of surface and bottom waters. The renewal of bottom water was mainly due to the northward transport of relatively cold waters, with strong influence of the South Atlantic Central Water (SACW). This water mass was, advected from the channel southern entrance, originated a bottom thermocline and pycnocline, besides almost homohaline conditions. The surface waters were influenced by the low salinity Coastal Water brought to the channel by southward currents.

The intrusion of the SACW across the southern channel entrance brings the Bottom
Thermal Front to the SSC during summer. When this happens, a strong two layer vertical structure typical of the baroclinic first mode can be observed within the channel.

Temperature and salinity fields are almost horizontally homogeneous. The vertical stratification was found to be more pronounced in subsurface layers due to the advection of the SACW. Despite the large temperature and salinity variations (17.0 to $30.0^{\circ} \mathrm{C}$ and 31.0 to $34.5 \%$, respectively), the composite $\mathrm{T}$-S diagram indicates small scattering between each observation period. Consequently, if thermohaline indexes of the original water masses are assigned, we can propose the use of the diagram to study formation and mixing of water masses in this coastal channel. 


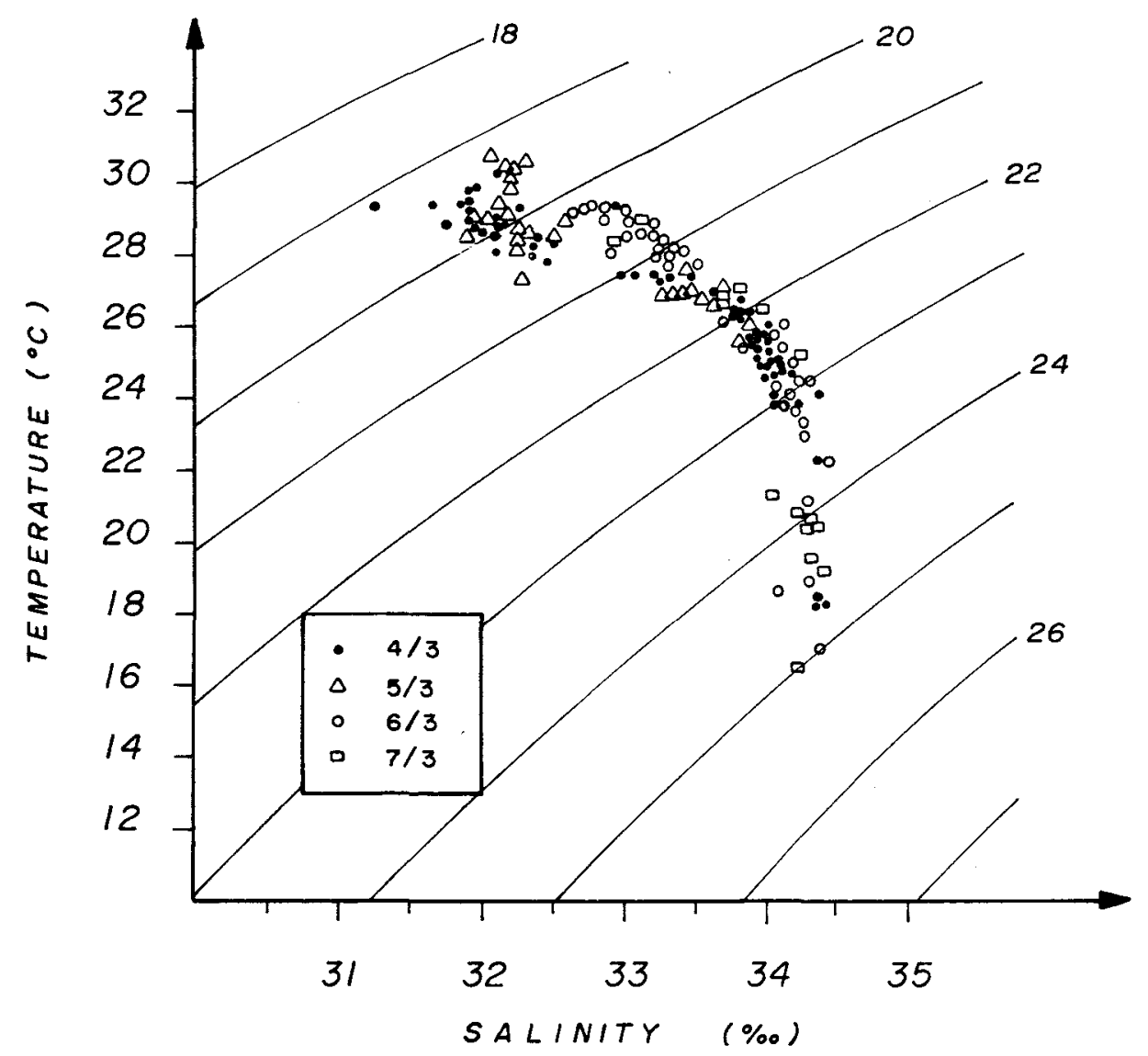

Fig. 12. Scatter T-S diagram from hydrographic properties observed from March 4 to March 7, 1980.

\section{Acknowledgements}

The field work was made possible by a grant from the Organization of the American States (Multinational Project on Marine Sciences, BR-19CA-A), and data analysis by funding from the Conselho Nacional de Desenvolvimento Científico e Tecnológico (CNPq, Proc. 303877/86-3 e Proc. 301014/79-5).

\section{References}

Castro, B. M. 1985. Subtidal response to wind forcing in the South Brazil Bight during winter. Ph.D. Thesis. Miami, University of Miami. $211 \mathrm{p}$.

Castro, B. M. 1990. Wind driven currents in the Channel of São Sebastião: winter, 1979. Bolm Inst. oceanogr., S Paulo, 38(2):111-132.

Castro, B. M. 1996. Correntes e massas de água da plataforma continental norte de São Paulo. Tese de livre-docência. Universidade de São Paulo, Instituto Oceanográfico. $248 \mathrm{p}$.
Castro, B. M. \& Lee, T. N. 1995. Wind-forced sea level variability on the southeast Brazilian shelf. J. Geophys. Res., 100(C8):16045-16056.

Castro, B. M.; Miranda, L. B. de \& Miyao, S. Y. 1987. Condições oceanográficas na plataforma continental ao largo de Ubatuba: variações sazonais em média escala. Bolm Inst. oceanogr., S Paulo, 35(2):135-151.

Coelho, A. L. 1997. Massas de água e circulação no Canal de São Sebastião (SP). Dissertação de mestrado. Universidade de São Paulo, Instituto Oceanográfico. $244 \mathrm{p}$.

Emilsson, I. 1962. As correntes marítimas no Canal de São Sebastião. Ciência Cult., S Paulo, 14(4):269-270.

Fontes, R. F. C. 1995. As correntes no Canal de São Sebastião. Dissertação de mestrado. Universidade de São Paulo, Instituto Oceanográfico. 159 p. 
Furtado, V. V. 1978. Contribuição ao estudo da sedimentação atual no Canal de São Sebastião. Tese de doutorado. Universidade de São Paulo, Instituto de Geociências. 2 v.

Furtado, V. V.; Gallo, J. \& †Luedemann, E. F. 1987. Análise do comportamento das correntes através de corpos de deriva no Canal de São Sebastião, São Paulo. In: CONGRESSO BRASILEIRO DE ESTUDOS DO QUATERNÁRIO, 1. Porto Alegre, 1987. Anais. Porto Alegre, ABEQUA. p.93-102.

Kvinge, T. 1967. On the special current and water level variations in the Channel of São Sebastião. Bolm Inst. oceanogr., S Paulo, (16):23-38.

Miranda, L. B. de 1982. Análise de massas de água da plataforma continental e da região oceânica adjacente: Cabo de São Tomé (RJ) e a Ilha de São Sebastião(SP). Tese de livre-docência. Universidade de São Paulo, Instituto Oceanográfico. $123 \mathrm{p}$.
Miranda, L. B. de \& Katsuragawa, M. 1991. Estrutura térmica na região sudeste do Brasil (outubro/novembro de 1988). Publção esp. Inst. oceanogr., S Paulo, (8):1-14.

Miranda, L. B. de \& Castro, B. M. 1995. Variabilidade da circulação e do transporte de volume no Canal de São Sebastião (SP). Publção esp. Inst. oceanogr., S Paulo, (11):1-9.

Silva, L. S. 1995. Condições oceanográficas no Canal de São Sebastião e na região costeira adjacente: variações sazonais entre fevereiro de 1994 a março de 1995. Dissertação de mestrado. Universidade de São Paulo, Instituto Oceanográfico. 128 p.

(Manuscript received 11 September 1997; revised 15 April 1998; accepted 24 August 1998) 